\title{
POMIAR RYZYKA RYNKOWEGO MIARĄ WARTOŚCI ZAGROŻONEJ. METODA KOMBINOWANIA PROGNOZ
}

\section{Wprowadzenie}

Zagadnienie zarządzania ryzykiem rynkowym i pomiaru tego ryzyka jest bardzo ważne dla badaczy, menedżerów i regulatorów rynku finansowego. Kryzys z roku 2007 pokazał, że nieodpowiednie zrozumienie narzędzi zarządzania i pomiaru ryzyka może być niebezpieczne nie tylko dla sektora finansowego, ale również dla całej sfery gospodarki realnej. Na ryzyko rynkowe narażone są głównie instytucje finansowe. Jajuga ${ }^{1}$ zauważa, że temat zarządzania ryzykiem dotyczy również innych podmiotów gospodarczych, takich jak przedsiębiorstwa czy podmioty sektora publicznego. Badania m.in. Adama i Fernando ${ }^{2}$, Cornaggiego ${ }^{3}$, Aretza i Bartrama ${ }^{4}$ pokazują, że wykorzystanie elementów zarządzania ryzykiem, takich jak zabezpieczające instrumenty pochodne, ma bezpośredni wpływ na zwiększenie wartości firmy lub wyniku finansowego.

Wartość zagrożona (Value at Risk - VaR) jest powszechnie wykorzystywanym narzędziem do pomiaru ryzyka rynkowego. Miara ta jest wykorzystywana przez większość instytucji finansowych ${ }^{5}$. Należy jednak pamiętać o ograniczeniach tej metody. Krytyka modeli ilościowych wykorzystywanych do pomiaru ryzyka wynika głównie $\mathrm{z}$ braku ich zrozumienia. Jak zauważa Jajuga ${ }^{6}$, modele pomiaru ryzyka powinny spełniać dwa warunki. Po pierwsze, powinny być odporne na zmiany rynkowe. Po drugie,

Doktorant, Akademia Leona Koźmińskiego.

K. Jajuga, Zarzadzanie ryzykiem, PWN, Warszawa 2007.

2 T.R. Adam, C.S. Fernando, Hedging, speculation, and shareholder value, „Journal of Financial Economics" No. 2, 2006, s. 283-309.

3 J. Cornaggia, Does risk management matter? Evidence from the U.S. agricultural industry, „Journal of Financial Economics" No. 2, 2013, s. 419-440.

4 K. Aretz, S. Bartram, Corporate hedging and shareholder value, „SSRN Scholarly Paper. Rochester, N.Y.: Social Science Research Network" 2009.

5 C. Alexander, Market risk analysis, Vol. 4, Wiley, Chichester 2008, s. 1.

6 K. Jajuga, Wykład przedstawiony przez Profesora Krzysztofa Jajuge podczas uroczystości nadania tytułu doktora honoris causa Uniwersytetu Ekonomicznego w Krakowie, Kraków 2012, s. 8, https://www.ue.wroc. pl/p/wyklad_prof_jajuga.doc [dostęp 21.11.2017]. 
powinny być przejrzyste dla użytkowników. Spełnienie drugiego warunku zmniejsza ryzyko nieodpowiedniego zastosowania modelu wynikające z niezrozumienia go.

Ze względu na praktyczną funkcjonalność modeli VaR miara ta stała się przedmiotem badań wielu teoretyków akademickich. Przegląd metod prognozowania wartości zagrożonej został opisany w artykułach Niety i Ruiza ${ }^{7}$, Abada i in. ${ }^{8}$ Propozycje modeli prognozowania wartości zagrożonej przyrastają w bardzo szybkim tempie. Oprócz standardowych modeli prognozowania VaR opisanych w tym artykule, w literaturze przedmiotu pojawiają się propozycje modeli wykorzystujących np. dane wysokiej częstotliwości, wykorzystujące multifraktalne własności szeregów czasowych czy też modele zmiany stanu.

Analizując literaturę przedmiotu z ostatnich kilku lat, można zauważyć, że pojawiają się artykuły wykorzystujące metodę kombinowania prognoz $\mathrm{VaR}^{9}$. Metoda kombinowania prognoz została opisana przez Batesa i Grangera ${ }^{10} \mathrm{i}$ jest popularnym narzędziem do prognozowania wskaźników ekonomicznych. Prostota tej koncepcji pozwala w łatwy sposób wykorzystać dane pochodzące z różnych źródeł i zmniejszyć ryzyko dużych błędów prognoz.

Celem artykułu jest analiza metod prognozowania wartości zagrożonej ze szczególnym uwzględnieniem metody kombinowania prognoz VaR i próba uporządkowania istniejących badań na ten temat.

\section{Definicja wartości zagrożonej i warunkowej wartości zagrożonej}

Value at Risk można zdefiniować jako oczekiwaną wielkość straty rynkowej portfela aktywów, którą przy określonym poziomie ufności i przy założeniu normalnych warunków rynkowych można ponieść w określonym czasie. Definicja matematyczna tej miary wygląda następująco:

$$
P\left(X<V_{a, t}\right)=\alpha
$$

\footnotetext{
7 M. Nieto, E. Ruiz, Frontiers in VaR forecasting and backtesting, „International Journal of Forecasting” No. 2, 2016, s. 475-501.

8 P. Abad, S. Benito, C. López, A comprehensive review of Value at Risk methodologies, „The Spanish Review of Financial Economics" No. 1, 2014, s. 15-32.

9 M. Nieto, E. Ruiz, op.cit.; P. Abad, S. Benito, C. López, op.cit.

10 J.M. Bates, C.W.J. Granger, The combination of forecasts, „Journal of the Operational Research Society" No. 4, 1969, s. 451-68.
} 
gdzie:

$X$ - zmienna losowa,

$\alpha$ - poziom prawdopodobieństwa,

$t$ - horyzont czasowy.

Miara VaR ma liczne zalety, przez które zyskała dużą popularność. Alexander ${ }^{11}$ wymienia kilka z nich:

- jest to miara łatwa do interpretowania ze względu na to, że jest wyrażana jedną liczbą (kwota możliwej straty),

- mierzy ryzyko związane z różnymi czynnikami,

- może być porównywana pomiędzy różnymi rynkami,

- miara ta może być stosowana dla różnych grup produktów oraz rodzajów ryzyka,

- może być wykorzystywana zarówno dla pojedynczego składnika aktywów, portfela aktywów, jak i całej instytucji,

- $\quad$ przy agregacji ryzyka aktywów uwzględnia ona współzależności między aktywami. Pomimo wymienionych zalet wartość informacyjna tej miary nie jest pełna. Nie informuje ona o stratach, jakie mogą być poniesione po przekroczeniu wartości zagrożonej. Jest to jej duża wada i przy niewłaściwym zrozumieniu tego, jak działa, może stwarzać zagrożenie błędnej interpretacji. Kolejną wadą tej miary jest brak koherentności ${ }^{12}$. Następny problem z VaR związany jest $\mathrm{z}$ wyborem metody szacowania VaR. W zależności od wybranej metody prognoza VaR może się różnić. Metoda szacowania powinna być wybierana w taki sposób, aby nie stwarzać problemu błędnego zrozumienia i błędnej interpretacji modelu.

Krytyka VaR w sposób naturalny stworzyła pole dla konkurencyjnych propozycji. Szczególnie warta uwagi jest miara CVaR (Conditional Value at Risk). Jest to miara koherentna i, według wielu badaczy, może stać się w przyszłości miarą, która zastąpi VaR w praktycznym wykorzystaniu. Warto jednak zwrócić uwagę na fakt, iż miara CVaR została zaproponowana przeszło 17 lat temu i do tej pory nie jest to miara dominująca w wykorzystaniu praktycznym w bankach, instytucjach finansowych $\mathrm{i}$ innych przedsiębiorstwach.

Miara ryzyka powinna spełniać pewne intuicyjne własności. Dla portfela aktywów powinna być mniejsza niż suma miar ryzyka pojedynczych składników aktywów wchodzących w skład portfela (subaddytywność). Niespełnienie tej własności jest bardzo mało intuicyjne i kłopotliwe przy interpretacji. W przypadku miary VaR ta własność nie zachodzi. Kolejną pożądaną własnością jest to, aby dołączenie do portfela składnika aktywów wolnego od ryzyka nie zwiększało ryzyka całego portfela

11 C. Alexander, op.cit., s. 1-2.

12 Koherencja - spoistość, spójność, zgodność. 
(niezmienniczość translacji). Inną własnością koherentnej miary ryzyka jest to, że dodanie składnika aktywów do portfela wpływa liniowo na ekspozycję na ryzyko (pozytywna homogeniczność). Ostatnia własność określa spełnienie następującej zależności: miara ryzyka odzwierciedla faktyczną relację między aktywami pod względem ich ryzykowności (monotoniczność). Wszystkie te wymagania spełnia miara warunkowej wartości zagrożonej ${ }^{13}$.

Miara ta została zaproponowana przez Rockafellara i Uryaseva ${ }^{14}$ i zdefiniowana jest jako wartość oczekiwana strat po przekroczeniu wartości zagrożonej. Definicja matematyczna wygląda następująco ${ }^{15}$ :

$$
C V a R_{\alpha, t}=E\left(X \mid X>V a R_{\alpha, t}\right)
$$

gdzie:

$V a R_{\alpha, t}$ - wartość zagrożona VaR,

$\alpha$ - kwantyl rozkładu,

$t$ - horyzont szacowanej miary ryzyka,

$X$ - zmienna losowa.

Opracowania na temat CVaR i przegląd metod jej szacowania można znaleźć w badaniach Brandtnera i Kürstena ${ }^{16}$, Koziorowskiej ${ }^{17}$, a także Rockafellara i Uryaseva ${ }^{18}$.

\section{Metody wyznaczania VaR}

Kryteriów podziału metod szacowania VaR jest kilka. Alexander ${ }^{19}$ proponuje podział na metody parametryczne, symulacje historyczne i symulacje Monte Carlo. Nieto i Ruiz ${ }^{20}$ wprowadzają podział na metody jednoetapowe i dwuetapowe. Z kolei

13 M. Chlebus, op.cit., s. 9-12; K. Koziorowska, Warunkowa wartość zagrożona jako narzędzie do zarzadzania ryzykiem inwestycji finansowych, Wydawnictwo UE w Poznaniu, Poznań 2011, s. 41-45.

14 R.T. Rockafellar, S. Uryasev, Optimization of conditional Value-at-Risk, „Journal of Risk” No. 2, 2000, s. $21-41$.

15 K. Dowd, An introduction to market risk measurement, Wiley, Chichester 2002, s. 29.

16 M. Brandtner, W. Kürsten, Solvency II, regulatory capital, and optimal reinsurance: How good are Conditional Value-at-Risk and spectral risk measures?, „Insurance: Mathematics and Economics” No. C, 2014, s. $156-167$.

17 K. Koziorowska, op.cit.

18 R.T. Rockafellar, S. Uryasev, op.cit.

19 C. Alexander, op.cit.

20 M. Nieto, E. Ruiz, op.cit. 
Abad i in. ${ }^{21}$ wyróżniają metody parametryczne, nieparametryczne i semiparametryczne. Metody nieparametryczne wyznaczają VaR bezpośrednio z danych empirycznych, bez szacowania parametrów rozkładu. Metody parametryczne szacują parametry potrzebne do wyznaczenia rozkładu badanej zmiennej. Metody semiparametryczne łączą obydwa te podejścia.

\subsection{Metody nieparametryczne}

Najbardziej powszechną metodą nieparametryczną jest metoda symulacji historycznej. Jest to metoda najczęściej używana w praktyce. Polega na wyznaczeniu odpowiedniego percentyla rozkładu stóp zwrotu przy wykorzystaniu do tego danych historycznych. Przy wyznaczaniu percentyla rozkładu należy zwrócić uwagę na dwa parametry. Pierwszym parametrem jest liczba jednostek czasu, na podstawie której wyliczana jest miara. Parametr ten jest również nazywany w literaturze „oknem”. Drugi parametr to odpowiedni percentyl rozkładu. Jest on bezpośrednio związany z tym, dla jakiego poziomu istotności liczona jest miara Value at Risk.

Metoda ta ma swoje wady i zalety. Niewątpliwie największą jej zaletą jest łatwość implementacji. Sprawia to, że jest to metoda najczęściej wykorzystywana w praktyce. W odróżnieniu od bardzo specjalistycznych i wymagających dużej wiedzy statystycznej metod ekonometrycznych szacowania VaR jest ona narażona na małe ryzyko błędnego stosowania. W literaturze przedmiotu metoda historyczna jest często krytykowana $\mathrm{z}$ kilku powodów.

Pierwszym $z$ nich jest fakt, iż zakłada ona równy wpływ każdej z obserwacji historycznych, bez względu na jej odległość w czasie. W praktyce oznacza to, że niekorzystne zdarzenie na rynku, które miało miejsce rok temu, ma takie samo znaczenie jak to, które wydarzyło się wczoraj. Ponadto, jak wskazują badania Abad i Mueli²2 oraz Pritskera $^{23}$, wyniki szacowania VaR metodą historyczną są mniej dokładne. Dodanie jednej dodatkowej obserwacji może znacząco zmienić wynik. Metoda symulacji historycznej jest często wykorzystywana jako metoda benchmarkowa i porównywana $\mathrm{z}$ innymi metodami. Innymi mniej popularnymi metodami nieparametrycznymi są jądrowe estymatory gęstości. Więcej na temat można znaleźć w pracy Harveya i Oryshchenki ${ }^{24}$.

21 P. Abad, S. Benito, C. López, op.cit.

22 P. Abad, S. Muela, A detailed comparison of Value at Risk in international stock exchanges, „Working Paper: Documentos de Trabajo FUNCAS" No. 452, 2009.

23 M. Pritsker, The hidden dangers of historical simulation, „Journal of Banking \& Finance” No. 2, 2006, s. $561-582$.

24 A. Harvey, V. Oryshchenko, Kernel density estimation for time series data, „International Journal of Forecasting, Special Section 1: The Predictability of Financial Markets” No. 1, 2012, s. 3-14. 


\subsection{Metody parametryczne}

Pierwszą z metod parametrycznych wykorzystywanych do szacowania VaR była metoda zaproponowana przez J.P. Morgan, zwana Risk Metrics ${ }^{25}$. Jest to szczególny przypadek modeli klasy EWMA (Exponential Weight Moving Average Model). Zakłada ona normalny rozkład błędu losowego. Modele EWMA można zapisać jako ważoną wykładniczo średnią poprzednich wartości warunkowej wariancji:

$$
\sigma_{t}^{2}(1-\omega) \sum_{j=0}^{N-1} \omega^{j}\left(\varepsilon_{t-j}\right)^{2}
$$

Pozwala to na uwzględnienie aktualnych poziomów wariancji. Przy niskich wartościach czynnika wygładzającego większe znaczenie mają nowsze wartości wariancji i mniejsze znaczenie starszych. W metodzie Risk Metrics parametr $\omega$ jest równy $0,94^{26}$. Value at Risk szacowana za pomocą tej metody określana jest jako ${ }^{27}$ :

$$
\operatorname{VaR}_{\alpha}(t)=\mu_{t}+z_{1-\alpha} * \sqrt{\hat{\sigma}_{t}^{2}}
$$

gdzie:

$\mu_{t}$ - wartość warunkowej wartości oczekiwanej w czasie $t$,

$z_{1-\alpha}$ - wartość kwantyla $\alpha$ standardowego rozkładu normalnego,

$\hat{\sigma}_{t}^{2}$ - oszacowanie warunkowej wariancji metodą EWMA w czasie $t$.

Kolejnym przykładem modeli parametrycznych są modele klasy ARCH (Autoregressive Conditional Heteroscedasticity). W modelach tej klasy również szacuje się warunkową wariancję. Zakłada się, że stopa zwrotu pochodzi z rozkładu i.i.d., $\mathrm{z}$ wartością oczekiwaną równą $\mu$ i wariancją równą $\sigma^{2}$. Modele klasy ARCH różnią się między sobą postacią równania wariancji. Mogą różnić się również przyjętymi założeniami dotyczącymi formy warunkowej wartości oczekiwanej czy rozkładu, z którego pochodzi błąd losowy. Modele tej klasy są odpowiedzią na jedną z najważniejszych własności finansowych szeregów czasowych, tzw. grupowania wariancji zauważonej przez Mandelbrota ${ }^{28}$. Wartość miary VaR wyznacza się tutaj analogicznie

25 J.P. Morgan/Reuters, „RiskMetrics TM - technical document”, Scribd 1996, https://pl.scribd.com/ document/211005929/J-P-Morgan-Reuters-RiskMetrics [dostęp 21.11.2017].

26 P. Abad, S. Benito, C. López, op.cit.

27 M. Chlebus, op.cit.

28 B. Mandelbrot, The variation of certain speculative prices, „The Journal of Business” Vol. 36, 1963. 
do równania [4]. Pierwszym modelem tej klasy był model zaproponowany przez Engle’a ${ }^{29}$. Można zapisać go w postaci:

$$
\begin{gathered}
r_{t}=\sqrt{\sigma^{2} \varepsilon_{t}} \\
\sigma^{2}=\omega+\sum_{i=1}^{q} \alpha_{i} \varepsilon_{t-i}^{2}
\end{gathered}
$$

gdzie:

$r_{t}$ - stopa zwrotu w momencie $t$,

$\sigma^{2}$ - warunkowa wariancja w momencie $t$,

$\varepsilon_{t}$ - błąd losowy o rozkładzie normalnym $N \sim(0,1)$,

$\omega$ - stała spełniająca warunek $\omega>0$.

Bollerslev $^{30}$ zaproponował rozszerzenie powyższej formuły o składnik autoregresyjny. W praktyce oznacza to, że warunkowa wariancja w momencie $t$ nie zależy tylko od błędu losowego w momencie $t-i$, ale również od warunkowej wariancji w momencie $t-i$. Model ten zapisać można jako:

$$
\sigma^{2}=\omega+\sum_{i=1}^{q} \alpha_{i} \varepsilon_{t-i}^{2}+\sum_{i=1}^{\rho} \beta_{i} \sigma_{t-i}^{2}
$$

$\mathrm{W}$ tym równaniu występuje dodatkowy parametr do oszacowania $\beta_{i}\left(\beta_{i} \geq 0\right)$.

Kolejni badacze rozszerzali równanie warunkowej wariancji o inne elementy. Jednym z nich jest uwzględnienie efektu dźwigni ${ }^{31}$. Modele pozwalające na rozróżnienie niesymetrycznego wpływu wzrostu i spadku cen portfela aktywów na szacowaną wartość zagrożoną zostały opisane m.in. przez Sentana ${ }^{32}$, Nelsona ${ }^{33}$, Glostena i in. ${ }^{34}$, Rabemananjarę i Zakoiana ${ }^{35}$. Tabela 1 zawiera kilka podstawowych modeli klasy ARCH.

29 R.F. Engle, Autoregressive conditional heteroscedasticity with estimates of the variance of United Kingdom inflation, „Econometrica” No. 4, 1982, s. 987-1007.

30 T. Bollerslev, Generalized autoregressive conditional heteroskedasticity, „Journal of Econometrics” No. 3, 1986, s. 307-327.

31 Zob. K. Piontek, Modelowanie efektu dźwigni w finansowych szeregach czasowych, Katedra Inwestycji Finansowych i Ubezpieczeń,Wydawnictwo AE we Wrocławiu, Wrocław 2004.

32 E. Sentana, Quadratic ARCH models, „The Review of Economic Studies" No. 4, 1995, s. 639-661.

33 D.B. Nelson, Conditional heteroskedasticity in asset returns: A new approach, „Econometrica” No. 2, 1991, s. 347-370.

34 L.R. Glosten et al., On the relation between the expected value and the volatility of the nominal excess return on stocks, „The Journal of Finance” No. 5, 1993, s. 1779-1801.

35 R. Rabemananjara, J.M. Zakoian, Threshold ARCH models and asymmetries in volatility, „Journal of Applied Econometrics" No. 1, 1993, s. 31-49. 
Tabela 1. Równania warunkowej wariancji modeli klasy ARCH

\begin{tabular}{|l|l|c|}
\hline \multicolumn{1}{|c|}{ Model } & \multicolumn{1}{|c|}{ Równanie wariancji } & Zatożenia \\
\hline EGARCH (1,1) & $\log \left(\sigma_{t}^{2}\right)=\alpha_{0}+\gamma\left(\frac{\varepsilon_{t-1}}{\sigma_{t-1}}\right)+\alpha_{1}\left(\left|\frac{\varepsilon_{t-1}}{\sigma_{t-1}}\right|-\sqrt{\frac{2}{\pi}}\right)+\beta \log \left(\sigma_{t-1}^{2}\right)$ & $\alpha+\beta<1$ \\
\hline GJR-GARCH (1,1) & $\begin{array}{l}\sigma_{t}^{2}=\alpha_{0}+\alpha_{1} \varepsilon_{t-1}^{2}-\gamma \varepsilon_{t-1}^{2} S_{t-1}^{-}+\beta \sigma_{t-1}^{2}, \\
\text { jeżeli } \varepsilon_{t-1}<0 \text { to } S_{t-1}^{-}=1 \text { i } S_{t-1}^{-}=0 \mathrm{w} \text { innych przypadkach }\end{array}$ & $\alpha_{0}, \alpha_{1}, \beta>0$ i $\alpha+\beta<1$ \\
\hline TGARCH (1,1) & $\begin{array}{l}\sigma_{t}=\alpha_{1}+\alpha_{1}\left|\varepsilon_{t-1}\right|+\gamma \varepsilon_{t-1} S_{t-1}^{-}+\beta \sigma_{t-1}, \\
\text { jeżeli } \varepsilon_{t-1}<0 \text { to } S_{t-1}^{-}=1 \text { i } S_{t-1}^{-}=0 \mathrm{w} \text { innych przypadkach }\end{array}$ & $\alpha_{0}, \alpha_{1}, \beta>0$ i $\alpha+\beta<1$ \\
\hline AGARCH (1,1) & $\sigma_{t}^{2}=\alpha_{0}+\alpha_{1} \varepsilon_{t-1}^{2}+\gamma \varepsilon_{t-1}^{2}+\beta \sigma_{t-1}^{2}$ & $\alpha_{0}, \alpha_{1}, \beta>0$ i $\alpha+\beta<1$ \\
\hline
\end{tabular}

Źródło: Opracowanie własne na podstawie: P. Abad, S. Benito, C. López, A comprehensive review of Value at Risk methodologies, „The Spanish Review of Financial Economics” No. 1, 2014, s. 15-32.

\subsection{Metody semiparametryczne}

Leptokurtyczność rozkładów stóp zwrotów jest jedną z cech finansowych szeregów czasowych. Badania pokazują, że finansowe szeregi czasowe mają cechę grubych ogonów. To znaczy, że odnotowuje się więcej obserwacji skrajnych, niż wynikałoby to $\mathrm{z}$ rozkładu normalnego, co może być problematyczne w kontekście prognozowania VaR. Zatem przyjęcie prostego rozkładu normalnego jest błędne. W tym przypadku należy dokonać empirycznej poprawki stóp zwrotu. Na takiej właśnie zasadzie działają modele semiparametryczne. Jest to metoda, która łączy modele parametryczne z nieparametrycznymi. Wykorzystuje się tutaj inny rozkład stóp zwrotów np. rozkład t-Studenta.

W literaturze można znaleźć bardzo dużo modeli szacowania wartości zagrożonej. Rozpiętość ich skomplikowania jest duża. Z jednej strony w ostatnich latach powstało dużo wyrafinowanych modeli ekonometrycznych, m.in. modele wykorzystujące właściwości fraktalne szeregów czasowych, dane wysokiej częstotliwości $\mathrm{i}$ inne. $\mathrm{Z}$ drugiej jednak strony w praktyce nadal wykorzystywane są proste metody wyznaczania VaR. Mimo że dają one wyniki charakteryzujące się na ogół mniejszą dokładnością, są bardziej zrozumiałe dla odbiorców. Nie ma w literaturze zgodności, które metody są najlepsze. Można stwierdzić, że dostarczanie stabilnych wyników i na ogół obarczenie małym błędem są cechami charakterystycznymi modeli warunkowej wariancji ARCH/GARCH. Badania wskazują na bardzo dobre wyniki modeli semiparametrycznych. Są to jednak modele dość skomplikowane od strony matematycznej. 


\section{Kombinowanie prognoz}

Jeśli najlepszy model jest nieznany lub może zmieniać się z upływem czasu, obiecującą alternatywą dla podejmowania decyzji o wyborze modelu pomiaru ryzyka jest połączenie oszacowań wynikających z kilku podejść. Elliott i in. ${ }^{36}$ podają trzy argumenty na korzyść kombinowania prognoz. Po pierwsze, prognozy kombinowane wykorzystują szerszy zakres informacji, założeń i specyfikacji. Po drugie, prognozy kombinowane są mniej ryzykowne w przypadku załamań strukturalnych lub zmian stanu rynku. Po trzecie, łączenie prognoz zmniejsza ryzyko dużego błędu w przypadku złej specyfikacji pojedynczego modelu. Trzeci argument jest szczególnie ważny w przypadku niesymetrycznej funkcji straty - gdy błąd prognozy jest bardzo kosztowny. Armstrong i in. ${ }^{37}$ zauważają, że „konserwatyzm” w prognozowaniu może znacznie zmniejszyć błąd prognozy. W jego ocenie, przy bardzo rozwiniętych i skomplikowanych metodach prognozowania, opieranie się na jednym modelu jest ryzykowne. W przeglądzie ponad stu artykułów - z czego około 40 dotyczyło metod kombinowania prognoz - zauważa, że łączenie modeli może zredukować błąd prognozy o blisko $15 \%$.

Model kombinowany w najprostszej postaci wygląda następująco ${ }^{38}$ :

$$
f_{c t}=w_{t} f_{1 t}+\left(1-w_{t}\right) f_{2}
$$

gdzie:

$t$ - okres, na który jest tworzona prognoza,

$w$ - waga prognozy pierwszej,

$f_{1}$ i $f_{2}$ - prognozy modelu pierwszego i drugiego.

W przypadku takiego równania najważniejszym elementem jest dobranie odpowiednich współczynników $w$, zgodnie z zasadą, iż „lepsza” prognoza „wchodzi” do modelu $\mathrm{z}$ większą wagą. Clemen ${ }^{39} \mathrm{~W}$ szerokim przeglądzie ponad 200 artykułów z dziedziny prognozowania, statystyki, zarządzania i psychologii dowodzi, że najprostsza metoda - średnia arytmetyczna - daje najlepsze wyniki. Inne metody wykorzystują analizy błędów prognoz indywidualnych z okresów poprzednich. Można sobie

36 G. Elliott et al., Handbook of economic forecasting, Elsevier, North Holland 2006, s. 137-140.

37 J.S. Armstrong et al., Golden rule of forecasting: Be conservative, „Journal of Business Research, Special Issue on Simple Versus Complex Forecasting” No. 8, 2015, s. 1717-1731.

38 Taki model można rozwinąć dla większej liczby prognoz indywidualnych, należy jednak pamiętać, że suma współczynników musi równać się jedności.

39 R.T. Clemen, Combining forecasts: A review and annotated bibliography, „International Journal of Forecasting" No. 4, 1989, s. 559-583. 
wyobrazić też sytuację, gdzie o tym, z jaką wagą wchodzi prognoza indywidualna, decyduje czynnik trzeci. Takim czynnikiem może być np. prognoza stanu rynku. Jeśli istnieje jakościowa różnica między poszczególnymi modelami indywidualnymi w różnych stanach rynku, taki dodatkowy czynnik mógłby znacząco ułatwić dobór wag dla prognoz indywidualnych.

Metoda łączenia prognoz wykorzystywana jest głównie w prognozowaniu wskaźników ekonomicznych takich jak stopa inflacji czy wzrost PKB ${ }^{40}$. Kombinowanie prognoz zostało również wykorzystane w prognozowaniu wyników wyborów, gdzie daje bardzo obiecujące wyniki ${ }^{41}$.

Jeon i Taylor ${ }^{42}$ stosują metodę kombinowania prognoz do wyznaczania miary VaR. W tym celu używają dwóch metod, które oparte są na różnych źródłach danych - oczekiwania rynku i informacje historyczne z szeregu czasowego. Do pierwszego zestawu informacji wykorzystują koncepcję zmienności implikowanej, będącą w pewnym sensie oczekiwaniem inwestorów na temat ryzyka konkretnego instrumentu finansowego, na który wystawiana jest opcja. $Z$ drugiej strony stosują jeden $\mathrm{z}$ semiparametrycznych modeli szeregów czasowych CaViaR. Autorzy zauważają, że w literaturze nie ma pełnej zgodności, która metoda jest lepsza - czy ta wykorzystująca zmienność historyczną, czy zmienność implikowaną. W takim przypadku połączenie tych dwóch podejść może znacznie zwiększyć zakres informacyjny, z którego korzysta się przy tworzeniu prognozy. Aby sprawdzić stabilność modeli kombinowania, testują różne techniki łączenia modeli, m.in. prostą średnią, średnią ważoną, kombinację liniową dwóch modeli. Przeprowadzają badanie empiryczne dla dwóch rynków rozwiniętych - niemieckiego (DAX) i amerykańskiego (S\&P500). Na podstawie wyników badania dochodzą do wniosku, że modele kombinowane w większości przypadków dają lepsze wyniki od modeli indywidualnych. Dodatkowo zauważają, że najlepsze wyniki dawały metody liniowego łączenia prognoz i prosta średnia. Analogiczne ${ }^{43}$

40 R.T. Clemen, R.L. Winkler, Combining economic forecasts, „Journal of Business \& Economic Statistics” No. 11986, s. 39-46; D.E. Rapach, J.K. Strauss, Forecasting US employment growth using forecast combining methods, „Journal of Forecasting” No. 1, 2008, s. 75-93; H. Bjørnland, Does forecast combination improve Norges Bank inflation forecasts?, „Oxford Bulletin of Economics and Statistics” No. 2, 2012, s. 163-79; M. Greszta, W. Maciejewski, Kombinowanie prognoz gospodarki Polski, „Gospodarka Narodowa” No. 5-6, 2005, s. 49-61.

41 M.S. Lewis-Beck et al., The British general election: Synthetic forecasts, „Electoral Studies” No. 41, 2016, s. 264-268; D. Rothschild, Combining forecasts for elections: Accurate, relevant, and timely, „International Journal of Forecasting” No. 3, 2015, s. 952-964; A. Graefe et al., Combining forecasts: An application to elections, „International Journal of Forecasting” No. 1, 2014, s. 43-54.

42 J. Jeon, J.W. Taylor, Using CAViaR models with implied volatility for Value-at-Risk estimation, „Journal of Forecasting” No. 1, 2013, s. 62-74.

43 Analogiczne w sensie wykorzystania tych samych estymatorów i takich samych metod łączenia prognoz. Używa natomiast innych procedur backtestingowych. 
badanie dla rynku cen złota i ropy przeprowadza Ratuszny ${ }^{44}$. Autorka dochodzi jednak do innych wniosków. $Z$ jej badania wynika, że modele łączone nie poprawiły prognoz w porównaniu $\mathrm{z}$ modelami indywidualnymi. Wykorzystując takie podejście, można łączyć prognozy wartości zagrożonej z modeli wykorzystujących dane wysokiej częstotliwości z modelami tradycyjnymi. Poszerzyłoby to zakres informacyjny prognozy kombinowanej. Jest to temat warty dalszych badań empirycznych.

Zdecydowanie najczęściej spotykanym sposobem kombinowania prognoz jest łączenie modeli, które używają ten sam zestaw informacji, ale poszczególne modele szacowane są w inny sposób. McAleer i in. ${ }^{45}$ proponują zastosowanie kombinowania prognoz dla różnych modeli VaR. Sprawdzają szeroki zakres parametrycznych modeli indywidualnych (RiskMetrics i modele typu GARCH). Proponowaną metodę testują na rynku amerykańskim dla indeksu S\&P500 w trzech przedziałach czasowych - przed, w trakcie i po globalnym kryzysie finansowym 2008-2009. Biorąc pod uwagę fakt, że modele indywidualne mogą być niestabilne dla różnych okresów rynkowych, badają oni hipotezę, czy proste połączenie modeli może uodpornić prognozę na różne momenty rynku. Procedura backtestingowa dostarczyła dowodów na potwierdzenie hipotezy, że prognoza kombinowana, wykorzystująca medianę wszystkich prognoz, po pierwsze nie obciąża znacząco banków w kontekście dziennych wymogów kapitałowych wynikających z umowy Basel ${ }^{46}$, a po drugie jest odporna na zmienne warunki rynkowe. Wyniki są stabilne zarówno w okresie przed kryzysem, w trakcie, jak i po. Halbleib i Pohlmeier ${ }^{47}$ wykonują podobne porównanie modeli $\mathrm{w}$ podziale na różne okresy rynkowe związane $\mathrm{z}$ globalnym kryzysem finansowym. Swoją próbę dzielą na trzy okresy. Pierwszy, rozpoczynający się 1 stycznia i trwający do 17 lipca 2007 r., reprezentujący okres przed kryzysem. Drugi to okres rozpoczynającego się kryzysu i trwający od 18 lipca. Ostatni jest okresem załamania rynku rozpoczynający się 1 września 2008 r., pierwszego dnia miesiąca, w którym upadł bank Lehman Brothers. Okres badania kończy się 1 lipca 2009 r. Podziału tego dokonują w celu sprawdzenia różnic pomiędzy wynikami modeli w różnych okresach. Autorzy w badaniu testują szeroką gamę modeli parametrycznych zmiennej w czasie wariancji. Jako alternatywę dla opisanych w pełni

44 E. Ratuszny, Risk modeling of commodities using CAViaR models, the encompassing method and the combined forecasts, „Dynamic Econometric Models” No. 15, 2015, s. 129-156.

45 M. McAleer et al., GFC-robust risk management strategies under the Basel Accord, „International Review of Economics \& Finance" No. 27,2013, s. 97-111.

46 „Basel II: International convergence of capital measurement and capital standards: a revised framework", 2004, http://www.bis.org/publ/bcbs107.htm [dostęp 21.11.2017].

47 R. Halbleib, W. Pohlmeier, Improving the Value at Risk forecasts: Theory and evidence from the financial crisis, "Journal of Economic Dynamics and Control, Quantifying and Understanding Dysfunctions in Financial Markets" No. 8, 2012, s. 1212-1228. 
parametrycznych modeli rozważają jedno podejście nieparametryczne szacowania wartości VaR, a mianowicie symulację historyczną (HS), która jest bardzo popularna wśród praktyków, i jej rozszerzenie FHS (Filtered Historical Simulation). Do kombinowania modeli wykorzystują metody optymalizacyjne, za pomocą których dobierają wagi. Wnioski z badania można podzielić na dwa główne. Pierwszy wniosek dotyczy modeli indywidualnych i ich niestabilności w różnych okresach rynku. W okresach spokojnych modele na założeniach "normalnych" dają dobre wyniki, jednak w okresach kryzysowych są obarczone dużym błędem. Drugi wniosek można zreasumować: $w$ przeciwieństwie do modeli indywidualnych modele kombinowane są stabilne w różnych okresach, dla różnych typów aktywów i różnego okresu oceny. Bayer ${ }^{48}$ proponuje model kombinowany stworzony za pomocą regresji kwantylowej (Penelized Quantile Regression). Swoje badanie przeprowadza dla rynku amerykańskiego (portfel 30 aktywów z indeksu DJIA). Badanie wykorzystuje dane z 18 lat - od stycznia $1996 \mathrm{r}$. do końca roku 2014. Taki zakres czasowy pozwala na przetestowanie modeli w różnych warunkach rynkowych związanych z kryzysem. Dane te używa do wyestymowania 17 modeli indywidualnych: modeli nieparametrycznych, parametrycznego, a także modeli semiparametrycznych. Wnioski z badania są zbieżne z poprzednimi. $\mathrm{W}$ większości przypadków modele kombinowane dają lepsze wyniki od modeli indywidualnych, szczególnie dla bardziej skomplikowanych modeli kombinowanych. Proste metody kombinowania dają nieco gorsze wyniki i nie przewyższają wszystkich modeli indywidualnych, szczególnie modeli semiparametrycznych. Do takiego połączenia modeli można również użyć modeli wykorzystujących własności multifraktalne szeregów czasowych. Taki model proponują Lee i in. ${ }^{49}$ Ich połączenie z modelami typu GARCH lub modelami semiparametrycznymi mogłoby zwiększyć dokładność prognoz VaR.

Ostatnim sposobem kombinowania prognoz VaR, który można wyróżnić, jest połączenie modeli za pomocą dodatkowego modelu lub informacji rynkowej. Podejście w tym duchu przedstawia Chlebus ${ }^{50}$, testując modele wczesnego ostrzegania EWS do wyboru odpowiedniego modelu spośród tych „normalnych” i „konserwatywnych". Nie przedstawia on jednak koncepcji ważenia modeli, a jedynie zerojedynkowego przełączania ich. Można taką koncepcje rozszerzyć o rozmytą ocenę stanu rynku i odpowiedniego ważenia modeli.

48 S. Bayer, Combining Value-at-Risk forecasts using penalized quantile regressions, „Econometrics and Statistics" No. 24, 2017 [in press].

49 H. Leeet al., Multifractal Value at Risk model, „Physica A: Statistical Mechanics and its Applications” No. 451, 2016, s. 113-22.

50 M. Chlebus, EWS-GARCH: New regime switching approach to forecast Value-at-Risk, „Working Paper. Faculty of Economic Sciences", University of Warsaw 2016. 


\section{Podsumowanie}

Analiza badań dotyczących kombinowania prognoz VaR pozwala na podział ich na trzy kategorie. Pierwsza kategoria jest najbardziej popularna i jej autorzy używają modeli wykorzystujących ten sam zbiór informacji. Łącząc modele, w których używa się tych samych danych historycznych, nie poszerza się zbioru informacyjnego prognozy, ale można uodpornić ją na sytuację, w której model indywidualny straci odpowiednie własności prognostyczne. Łącząc takie modele, można zwiększyć stabilność prognozy w różnych warunkach rynkowych. W drugiej kategorii można umieścić badania, w których autorzy używają modeli, które wykorzystują różne zbiory informacji. Łączenie takich modeli może zwiększyć wartość informacyjną prognozy. Przykładem takiego połączenie może być kombinacja modeli używających danych wysokiej częstotliwości z modelami dziennych szeregów czasowych, a także modeli eksperckich z modelami szeregów czasowych. Warto jednak zaznaczyć, że obecnie nie ma wielu badań dotyczących takiego łączenia prognoz $\mathrm{VaR}$, a istniejące nie są ze sobą zgodne. Trzecia kategoria zaproponowana w powyższej analizie dotyczy łączenia prognoz VaR z wykorzystaniem dodatkowego modelu określającego wagi prognozy kombinowanej, np. na podstawie danych rynkowych. W przypadku gdy istnieje jakościowa różnica między modelami w różnych fazach rynku, można użyć modelu dodatkowego, który na podstawie dodatkowej informacji dobierze odpowiednią wagę. Takie podejście jest szczególnie istotne dla podmiotów, które oprócz odpowiedniego zabezpieczania się przed ryzykiem zwracają również uwagę na minimalizację kosztów utrzymywania kapitału.

Taka analiza literatury dotyczącej kombinowania prognoz VaR pozwala na określenie dalszych zamierzeń badawczych. Po pierwsze, metody analizowane $\mathrm{w}$ artykule zostaną przetestowane na polskim rynku kapitałowym. Takie sprawdzenie pozwoli odpowiedzieć na pytanie, czy istnieją jakościowe różnice między rozwiniętymi gospodarkami a gospodarką Polski lub gospodarkami krajów Europy Środkowej i Wschodniej. Po drugie, zostanie przetestowane połączenie modelu VaR, w którym wykorzystuje się multifraktalne własności szeregów czasowych z modelami parametrycznymi typu GARCH dla polskiego rynku akcji. Po trzecie, zostaną przetestowane metody wczesnego ostrzegania do wyznaczania odpowiednich wag modeli „normalnych” $i$ „konserwatywnych” w różnych stanach rynku. Takie badania mogą mieć walor aplikacyjny dla różnych instytucji finansowych i przedsiębiorstw. 


\section{Measurement of market risk by Value at Risk method}

The article discusses the measurement of market risk by Value at Risk method. Value at Risk measure is an important element of risk measurement mainly for financial institutions but can also be used by other companies. The Value at Risk is presented together with its alternative Conditional Value at Risk. The main methods of $\mathrm{VaR}$ estimation were divided into nonparametric, parametric and semi-parametric methods. The next part of the article presents a method of combining forecasts, which can be used in the context of forecasting Value at Risk.

Keywords: Value at Risk, VaR, market risk measurement, combining forecasts

\section{Literatura}

1. Abad P., Benito S., López C., A comprehensive review of Value at Risk methodologies, „The Spanish Review of Financial Economics” No. 1, 2014, s. 15-32.

2. Abad P., Muela S., A detailed comparison of Value at Risk in international stock exchanges, „Working Paper: Documentos de Trabajo FUNCAS” No. 452, 2009.

3. Adam T.R., Fernando C.S., Hedging, speculation, and shareholder value, „Journal of Financial Economics" No. 2, 2006, s. 283-309.

4. Alexander C., Market Risk Analysis, Vol. 4, Wiley, Chichester 2008.

5. Aretz K., Bartram S.M., Corporate hedging and shareholder value, „SSRN Scholarly Paper. Rochester, NY: Social Science Research Network" 2009.

6. Armstrong J.S. et al., Golden rule of forecasting: Be conservative, „Journal of Business Research, Special Issue on Simple Versus Complex Forecasting" No. 8, 2015, s. $1717-1731$.

7. „Basel II: International convergence of capital measurement and capital standards: a revised framework", 2004, http://www.bis.org/publ/bcbs107.htm

8. Bates J.M., Granger C.W.J., The combination of forecasts, „Journal of the Operational Research Society" No. 4, 1969, s. 451-468.

9. Bayer S., Combining Value at Risk forecasts using penalized quantile regressions, „Econometrics and Statistics" No. 24, 2017 [in press].

10. Bjørnland H. et al., Does forecast combination improve norges bank inflation forecasts?, „Oxford Bulletin of Economics and Statistics” No. 2, 2012, s. 163-179.

11. Bollerslev T., Generalized autoregressive conditional heteroskedasticity, „Journal of Econometrics" No. 3, 1986, s. 307-327. 
12. Brandtner M., Kürsten W., Solvency II, regulatory capital, and optimal reinsurance: How good are Conditional Value at Risk and spectral risk measures?, „Insurance: Mathematics and Economics" No. C, 2014, s. 156-167.

13. Chlebus M., EWS-GARCH: New regime switching approach to forecast Value at Risk, „Working Paper. Faculty of Economic Sciences”, University of Warsaw 2016.

14. Chlebus M., Pomiar ryzyka rynkowego za pomoca miary Value at Risk-podejście dwuetapowe, Wydział Nauk Ekonomicznych, Uniwersytet Warszawski, Warszawa 2014.

15. Clemen R.T., Combining forecasts: A review and annotated bibliography, „International Journal of Forecasting” No. 4, 1989, s. 559-583.

16. Clemen R.T., Winkler R.L., Combining economic forecasts, „Journal of Business \& Economic Statistics" No. 1, 1986, s. 39-46.

17. Cornaggia J., Does risk management matter? Evidence from the U.S. agricultural industry, „Journal of Financial Economics” No. 2, 2013, s. 419-440.

18. Dowd K., An introduction to market risk measurement, Wiley, Chichester 2002.

19. Elliott G. et al., Handbook of economic forecasting, Elsevier, North Holland 2006.

20. Engle R.F., Autoregressive conditional heteroscedasticity with estimates of the variance of United Kingdom inflation, „Econometrica” No. 4, 1982, s. 987-1007.

21. Glosten L.R. et al., On the relation between the expected value and the volatility of the nominal excess return on stocks, „The Journal of Finance” No. 5, 1993, s. 1779-1801.

22. Graefe A. et al., Combining forecasts: An application to elections, „International Journal of Forecasting" No. 1, 2014, s. 43-54.

23. Greszta M., Maciejewski W., Kombinowanie prognoz gospodarki Polski, „Gospodarka Narodowa" nr 5-6, 2005, s. 49-61.

24. Halbleib R., Pohlmeier W., Improving the Value at Risk forecasts: Theory and evidence from the financial crisis, „Journal of Economic Dynamics and Control, Quantifying and Understanding Dysfunctions in Financial Markets” No. 8, 2012, s. 1212-1228.

25. Harvey A., Oryshchenko V., Kernel density estimation for time series data, „International Journal of Forecasting, Special Section 1: The Predictability of Financial Markets" No. 1, 2012, s. 3-14.

26. Jajuga K., Wykład przedstawiony przez Profesora Krzysztofa Jajuge podczas uroczystości nadania tytułu doktora honoris causa Uniwersytetu Ekonomicznego w Krakowie, 2012, https://www.ue.wroc.pl/p/wyklad_prof_jajuga.doc

27. Jajuga K., Zarządzanie ryzykiem, PWN, Warszawa 2007.

28. Jeon J., Taylor J.W., Using CAViaR models with implied volatility for Value at Risk estimation, „Journal of Forecasting” No. 1, 2013, s. 62-74.

29. J.P. Morgan/Reuters, „Risk Metrics TM - technical document”, Scribd 1996, https:// pl.scribd.com/document/211005929/J-P-Morgan-Reuters-RiskMetrics

30. Koziorowska K., Warunkowa wartość zagrożona jako narzędzie do zarządzania ryzykiem inwestycji finansowych, Wydawnictwo UE w Poznaniu, Poznań 2011. 
31. Lee H. et al., Multifractal Value at Risk model, „Physica A: Statistical Mechanics and its Applications" No. C, 2016, s. 113-122.

32. Lewis-Beck M.S. et al., The British general election: synthetic forecasts, „Electoral Studies" No. C, 2016, s. 264-268.

33. Mandelbrot B., The variation of certain speculative prices, „The Journal of Business” No. 36, 1965, s. 394-394.

34. McAleer M. et al., GFC-robust risk management strategies under the Basel Accord, „International Review of Economics \& Finance” No. C, 2013, 97-111.

35. Nelson D.B., Conditional heteroskedasticity in asset returns: a new approach, „Econometrica" No. 2, 1991, s. 347-370.

36. Nieto M., Ruiz E., Frontiers in VaR forecasting and backtesting, „International Journal of Forecasting" No. 2, 2016, s. 475-501.

37. Piontek K., Modelowanie efektu dźwigni w finansowych szeregach czasowych, Katedra Inwestycji Finansowych i Ubezpieczeń Akademia Ekonomiczna we Wrocławiu, Wrocław 2004, http://www.kpiontek.ue.wroc.pl/dzwignia.pdf

38. Pritsker M., The hidden dangers of historical simulation, „Journal of Banking \& Finance” No. 2, 2006, s. 561-582.

39. Rabemananjara R., Zakoian J.M., Threshold ARCH models and asymmetries in volatility, „Journal of Applied Econometrics” No. 1,1993, s. 31-49.

40. Rapach D.E., Strauss J.K., Forecasting US employment growth using forecast combining methods, „Journal of Forecasting” No. 1, 2008, s. 75-93.

41. Ratuszny E., Risk modeling of commodities using CAViaR models, the encompassing method and the combined forecasts, „Dynamic Econometric Models” No. 15, 2015, s. $129-156$.

42. Rockafellar R.T., Uryasev S., Optimization of conditional Value at Risk, „Journal of Risk" No. 2, 2000, s. 21-41.

43. Rothschild D., Combining forecasts for elections: Accurate, relevant, and timely, „International Journal of Forecasting” No. 3, 2015, s. 952-964.

44. Sentana E., Quadratic ARCH models, „The Review of Economic Studies” No. 4, 1995, s. 639-661. 